\title{
Effect of some processing methods on the proximate, mineral, microbiological and sensory qualities of cowpea enriched maize snack (Ipekere Agbado)
}

\author{
Shakpo, I. O. ${ }^{1,2^{*}}$ and Osundahunsi, O. F. ${ }^{2}$ \\ ${ }^{1}$ Food Science and Technology Department, Rufus Giwa Polytechnic, Owo, Nigeria. \\ ${ }^{2}$ Food Science and Technology Department, Federal University of Technology, Akure, Nigeria. \\ ${ }^{*}$ Corresponding author. Email: de.kings.io@gmail.com. Tel: +2348036267170.
}

Copyright (@) 2016 Shakpo and Osundahunsi. This article remains permanently open access under the terms of the Creative Commons Attribution License 4.0, which permits unrestricted use, distribution, and reproduction in any medium, provided the original work is properly cited.

Received 23rd February, 2016; Accepted 4th May, 2016

\begin{abstract}
The development of cheap, readily available and nutritious snack from indigenous crops (maize and cowpea blend) was carried out and evaluated. The objective of the study was to increase the nutrient content of the snack with respect to protein and mineral. The effect of processing methods; oven-drying and oil-frying on the quality attributes of the snack was investigated. Flour blends were produced from maize and cowpea flours in the following ratios of maize:cowpea; 90:10, 80:20, 70:30 and 100:0. Stiff paste of the blends seasoned with onion and pepper was divided into two parts; the first part was molded and deep-fried in palm oil while the second part was oven-dried at $150^{\circ} \mathrm{C}$ for $2 \mathrm{~h}$. Analyses carried out on the snack include: proximate, mineral, microbiological and sensory evaluation. For the snacks produced, protein content ranged from 5.86 to $12.50 \%$, total ash, 2.32 to $4.32 \%$; fat content, 8.89 to $25.04 \%$; moisture content, 8.90 to $17.47 \%$ and fibre content ranged from 7.32 to $18.76 \%$. It was observed that fat content was not affected by cowpea substitution but by oil-frying. Fried samples gave higher value when compared with oven-dried samples. Conversely, oven-drying had a significant $(p \leq 0.05)$ effect on all the proximate contents except ash. Result of Minerals showed that potassium, sodium, zinc, and iron contents increased with increase in cowpea substitution in the snacks, with $30 \%$ cowpea substitution having the highest values. Microbiological evaluation for the snacks showed that total viable count ranged from 1.80 to $2.70 \times 10^{3} \mathrm{Cfu} / \mathrm{ml}$, while yeast and mould count ranged from 1.0 to $1.9 \times 10^{3}$ $\mathrm{Sfu} / \mathrm{ml}$. Sensory evaluation showed that there were significant differences $(p \leq 0.05)$ among the snacks produced in terms of aroma, appearance, texture (crispness), taste and overall acceptability. Oven-dried samples were scored lower than oil-fried in aroma, taste and overall acceptability but were preferred in terms of appearance and crispness. The overall result showed that $20 \%$ cowpea substitution is most adequate to produce an acceptable and nutritious snack ("ipekere agbado"). In conclusion, addition of protein-rich cowpea to traditionally and culturally acceptable snack will improve nutrient intake and livelihoods of the rural community.
\end{abstract}

Keywords: Cowpea, Ipekere agbado, maize, nutrient, nutritious snack, oil-frying, oven-drying.

\section{INTRODUCTION}

The most widely consumed snacks are cereal-based products, which generally are low in nutrient density (Rhee et al., 2004). According to FAO (1992), the protein content of maize ranges from 8 to $11 \%$, a variety of snack foods widely consumed by Nigerians are made of lowprotein cereals with lysine and tryptophan as limiting amino acids (Omueti et al., 1992) that are essential for human nutrition. Enrichment of such snacks becomes relevant for adequate contribution to total nutrient intake (Obatolu et al., 2006). Omueti and Morton (1996) reported that fortification of starch-based snack foods with suitable protein food would improve the nutritional quality. To ensure a wide consumption of good quality snack foods, enrichment of maize with cowpea in the preparation of snacks could be considered. Ipekere or Ipakere (maize snack) is a local snack common among 
the people of Ondo and Edo States (Nigeria). In Owo and Ifelodun Local Governments (Ondo State), it is known as Ipekere. In Akure, the State Capital, it is called Ipakere or Akara Agbado while the people of Akoko calls it Akara Agbado, it is commonly referred to as ikara oka in Auchi, Edo State. It is generally made by deep frying in palm oil, a stiff paste made from coarsely milled maize flour, spiced with onion, pepper and salt. It is an all-maize food product and is expected to be nutritionally inadequate (Giami et al., 2003). Cowpeas, though rich in protein, have been reported to be deficient in sulphur amino acids, particularly methionine (Giami et al., 2003). Maize when combined with cowpeas has been shown to have a complementary effect on the amino acid profile and, therefore, on the nutritive value of a mixture of cowpea and maize. Enriching maize with cowpea to produce a snack will certainly improve the nutritional composition of such snack with respect to protein, vitamins and mineral. In addition, production of snack from indigenous crop will certainly reduce dependence on foreign food crop like wheat. There is limited information about the nutrient composition of a maize snack enriched with cowpea flour, hence, the need for this study.

\section{MATERIALS AND METHODS}

Dried yellow maize (Zeamays), cowpea (Vigna unguiculata) and other ingredients (onion, fresh pepper, palm oil) used for this research were sourced from Obada market in Emure-ile, Owo Local Government Area of Ondo State, Nigeria. While the AAS (Model 210 VGP Buck Atomic Absorption Spectrophotometre) and flame photometre used for mineral determination were from the Chemistry Laboratory of Science Laboratory Technology department, Hot air oven (Model Memmert 854, Gallenkamp, UK), water bath (Model HH - 6), Kenwood mixer (Model A 907 D, Kenwood Ltd, England) and other equipment used for this research were from the Food Chemistry Laboratory of the Department of Food Science and Technology, Rufus Giwa Polytechnic, Owo, Ondo State. All chemicals used for the analyses were of analytical grade.

\section{Methods}

\section{Production of maize flour}

Maize flour was produced following the procedure adopted by Barber et al. (2010) with slight modification. The maize grains were sorted to remove extraneous matter, then washed with potable water and boiled for $1 \mathrm{~h}$ in a pressure pot. The drying was achieved with the aid of hot air oven (Memmert 854 , Gallenkamp, UK) at $65^{\circ} \mathrm{C}$ for $8 \mathrm{~h}$. The dried maize was milled into flour using attrition mill and was stored in air tight container until needed for further analysis.

\section{Production of Cowpea flour}

Matured and dried cowpea seeds were carefully cleaned, sorted to remove defective ones, stones and other extraneous matters. The cleaned seeds were soaked in potable water for just 20 min to soften the seed coat for easy dehulling. The dehulled cowpea was dried in hot air oven (Memmert 854 , Gallenkamp, UK) at $65^{\circ} \mathrm{C}$ for $24 \mathrm{~h}$ and milled into flour. The flour was stored in air-tight polythene until needed.

\section{Formulation}

The maize:cowpea flour blends were formulated into four ratios: 70:30; 80:20; 90:10 and 100:0 respectively, these were kept in air tight container until needed to be used (for analysis and thereafter production of fortified maize snack).

\section{Production of enriched maize snack (ipekere agbado)}

Enriched maize snack was produced following the procedure obtained from a local producer (unpublished) but with slight modification. As earlier stated, there has not been detailed research work on the production of this sort and Ipekere agbado had always been an all-maize product (Figure 2). However, for the purpose of this research, the formulated maize and cowpea flour blends were used and other ingredients were added as follows: flour $-250 \mathrm{~g}$, palm oil $-10 \mathrm{ml}$, salt $-4 \mathrm{~g}$, pepper $-25 \mathrm{~g}$, onion - $70 \mathrm{~g}$, water (warm) - $150 \mathrm{ml}$, these were mixed together to form a stiff dough and divided into two parts. One part was molded with palm and flattened, then deepfried in palm oil until dried and crispy (Figure 3). Constant turning was ensured to avoid being burnt and palm oil was changed intermittently to avoid undesirable crust colour as bleached oil is not suitable for the frying process. The second part was also molded and flattened but the frying process was replaced with oven-drying (in form of baking) at $150^{\circ} \mathrm{C}$ for $2 \mathrm{~h}$ (Figure 1) to investigate oven-drying as an alternative processing method. The resulting Ipekere agbado samples were allowed to cool to room temperature $\left(37^{\circ} \mathrm{C}\right)$ for $2 \mathrm{~h}$ before further analyses were carried out.

\section{Analyses}

The proximate analysis (moisture, ash, crude fat, crude fibre and crude protein contents) was carried out following the methods described by AOAC (1990). Carbohydrate was determined by percentage difference from other proximate parameters:

$\%$ Carbohydrate $=(100 \%-\{\%$ moisture $+\%$ crude fat + $\%$ crude protein $+\%$ crude fibre + ash contents $\}$ ) 


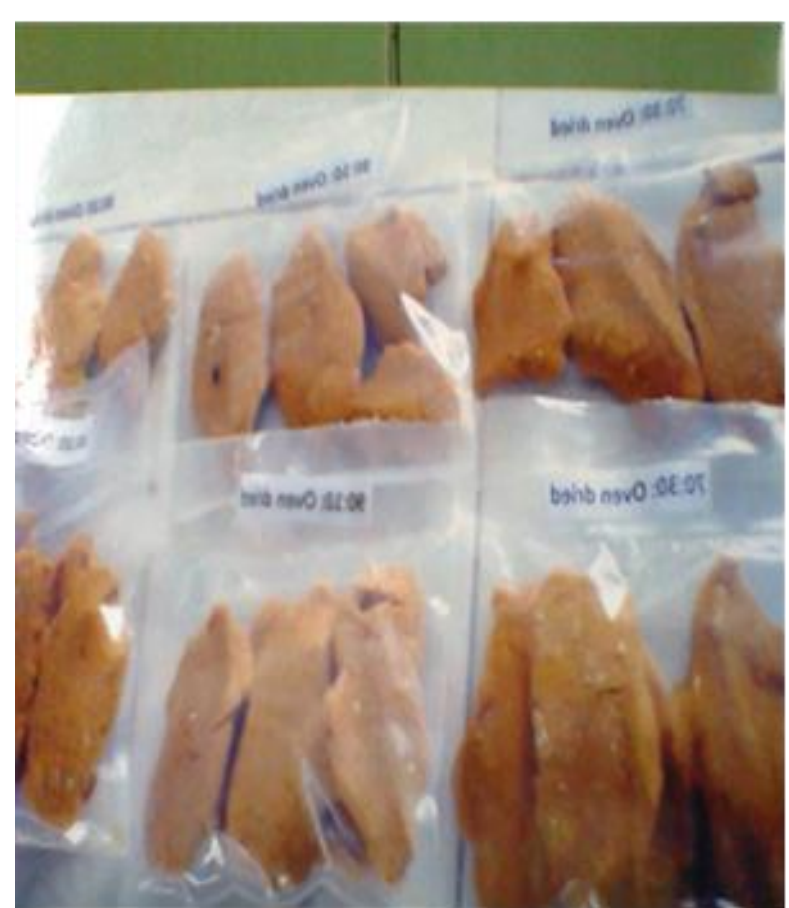

Figure 1. Oven dried samples of Ipekere agbado

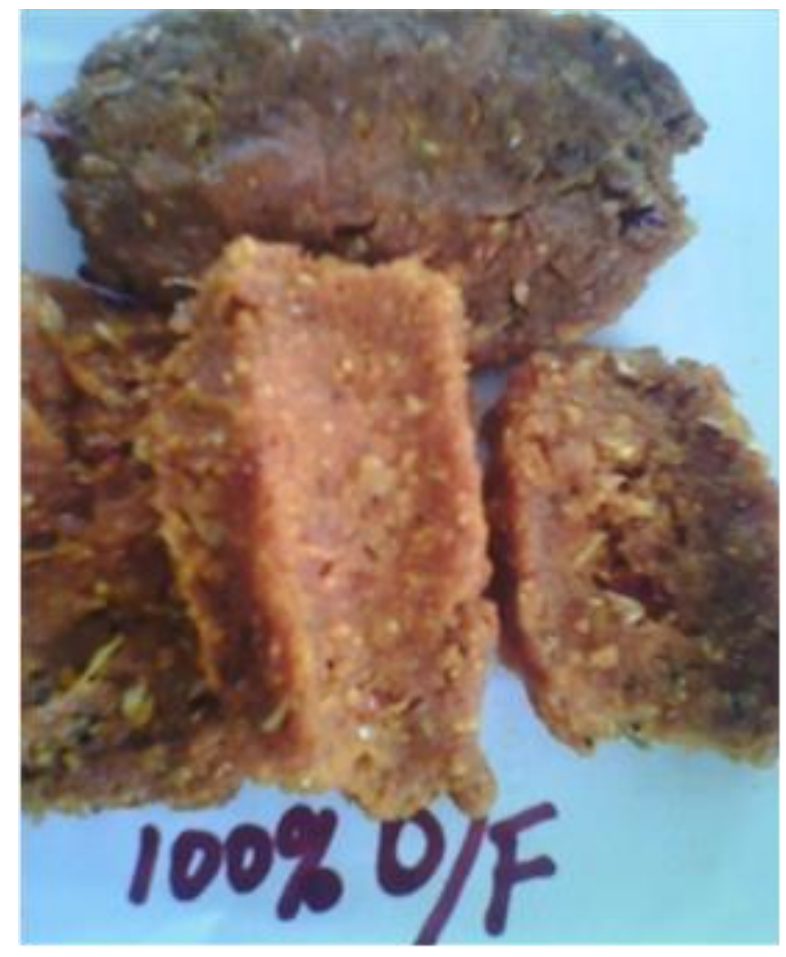

Figure 2. $100 \%$ maize from local producer of Ipekere agbado

\section{Determination of mineral content}

The mineral contents of the samples were determined after acid digestion of the ashed samples as follows: $2 \mathrm{ml}$ of aqua regia (mixture of $\mathrm{HCl}$ and $\mathrm{HNO}_{3}$ in ratio $3: 1$ ) was added to each ashed sample in $100 \mathrm{ml}$ flask and made up to the mark with distilled water. The solution was then filtered through N0.4 Whatman filter paper and the clear solution was kept in plastic bottle with lid. Calcium, Zinc and Iron were determined using Atomic Absorption Spectrophotometre (model 210 VGP Buck Atomic Absorption Spectrophotometre) while sodium and potassium were determined using flame photometre.

\section{Microbiological analysis}

The media used for microbiological analysis include Nutrient agar (NA), Eosine Methylene Blue (EMB) and Potato Dextrose Agar (PDA) for total viable count, coliform test and yeast and mould count respectively. These media were obtained from the Microbiology Laboratory of the Department of Food Science and Technology, Rufus Giwa Polytechnic, Owo and were prepared according to the manufacturer's instruction. The procedure described by Collins et al. (1989) as reported by Otunola et al. 2012 was used to evaluate the microbiological characteristics of the samples. The sample $(10 \mathrm{~g})$ was added to $100 \mathrm{ml}$ of distilled water and mixed thoroughly after which $1 \mathrm{ml}$ of the mixture was serially diluted for estimating the number of microorganisms.

\section{Sensory evaluation of enriched ipekere agbado}

The sensory attributes of the fortified ipekere samples were evaluated with ten taste panelists using nine (9) point hedonic scale rating as described by Iwe (2003). The samples were evaluated (Figure 4) on quality characteristics of appearance, taste, texture (crispness), aroma, and overall acceptability with 9 as like extremely and 1 as dislike extremely. The triplicate data of the result obtained were analysed statistically using ANOVA and the means separated using Duncan multiple range test. Panelists (comprising of staff and students who were also familiar with the sensory properties of the samples) were selected from the Departments of Food Science and Technology and Nutrition and Dietetics of Rufus Giwa Polytechnic, Owo, Nigeria.

\section{Statistical analysis}

The SPSS for windows programme version 15.0 was used to analyse the results obtained, means and standard deviation of all the samples were calculated and compared. The results obtained were in triplicate and subjected to analysis of variance ANOVA and the means were separated by New Duncan Multiple Range Test (NDMRT). 


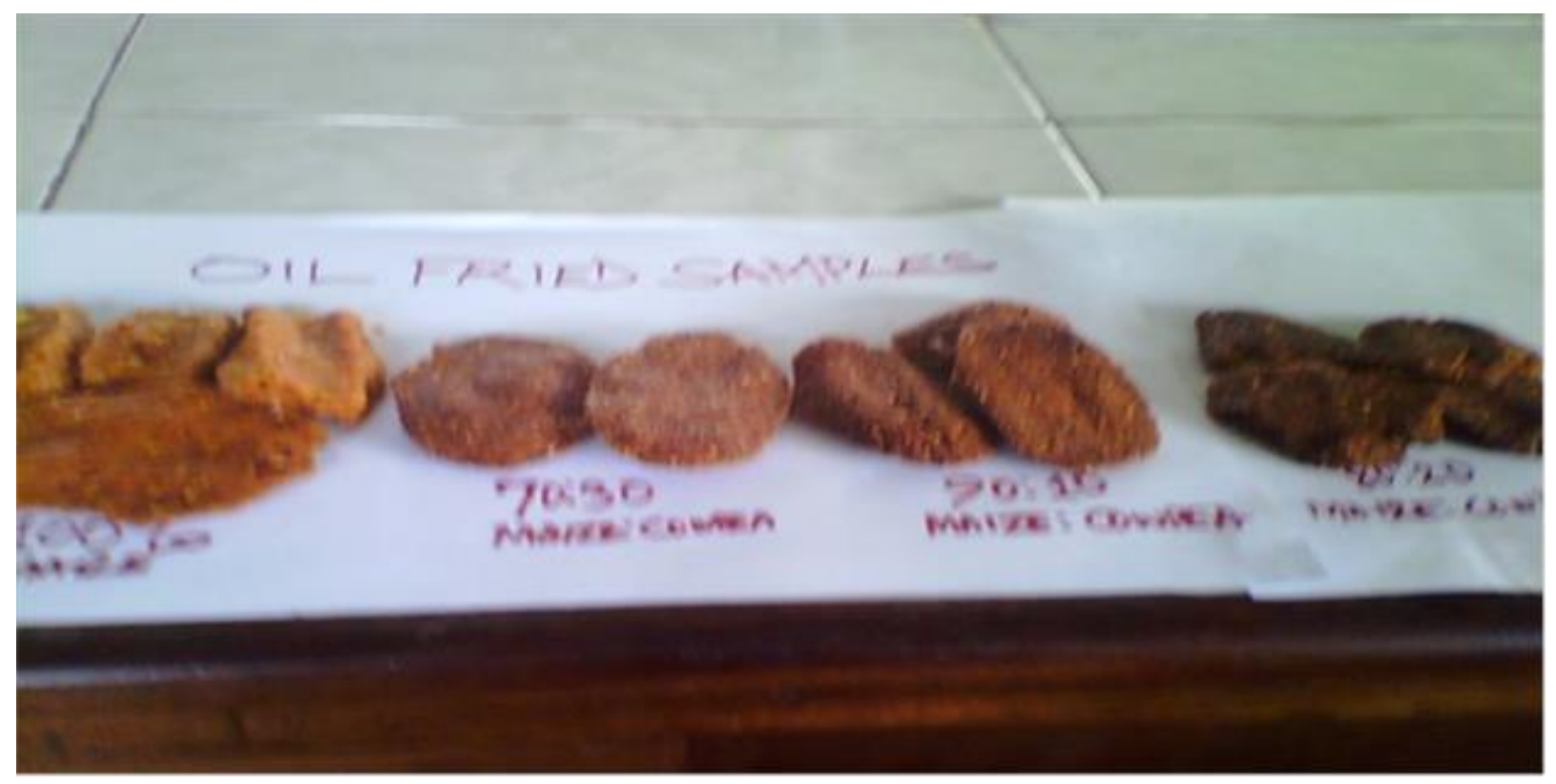

Figure 3. Oil fried samples of Ipekere agbado.

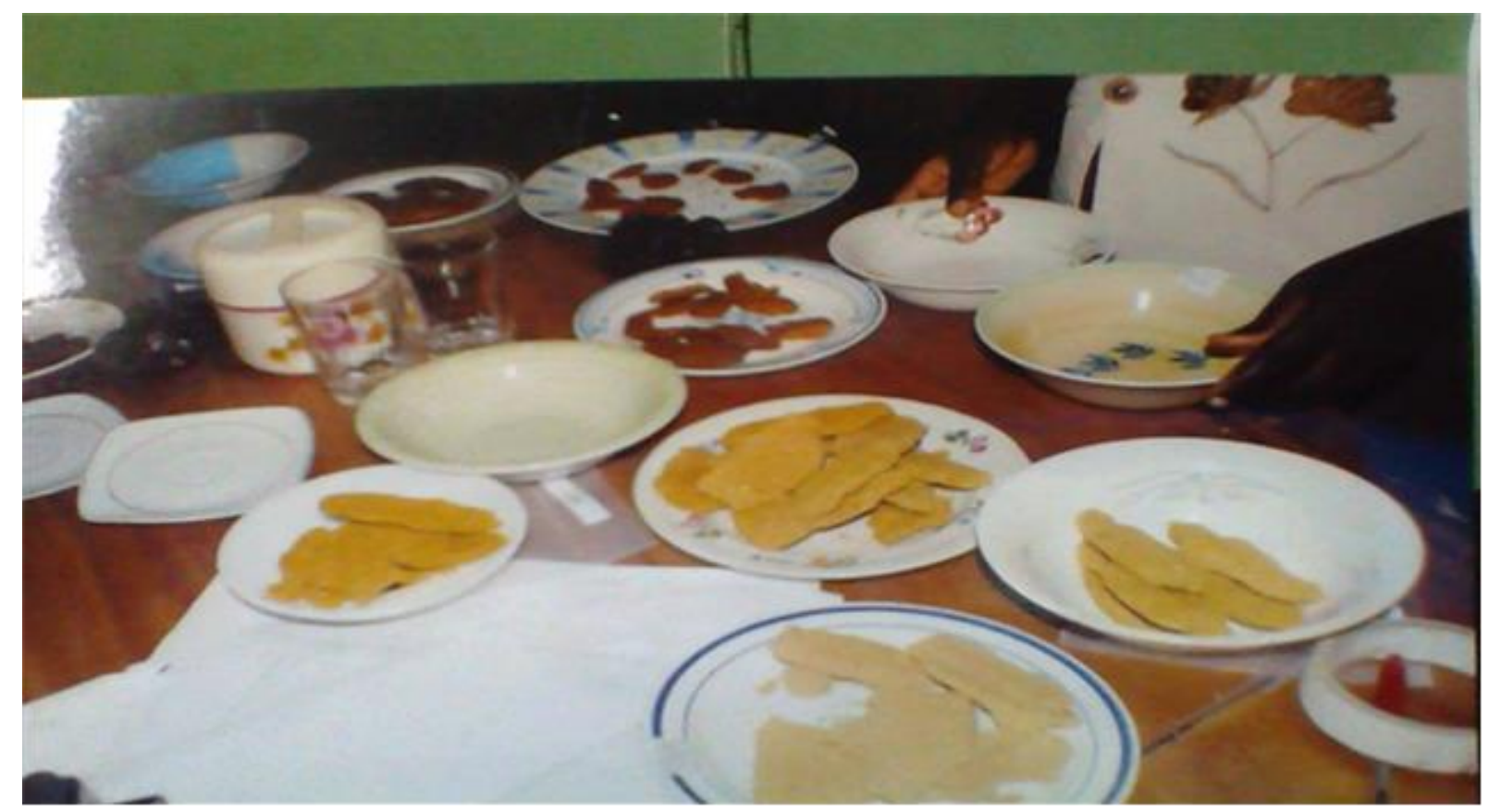

Figure 4. Preparation of samples for sensory evaluation.

\section{RESULTS AND DISCUSSION}

\section{Results}

\section{Proximate Composition of the Fortified Ipekere Agbado Samples}

The result of the proximate composition of the ipekere agbado samples is presented in Table 1. The moisture content of the samples ranged from 8.90 to $17.47 \%$, the least value was recorded for oven-dried sample with $100 \%$ maize flour while the highest value was recorded for oil-fried sample from $30 \%$ cowpea substitution. The moisture contents of the oven-dried samples were significantly different from those of the oil-fried samples with the oil-fried samples retaining more moisture than 
Table 1. Proximate Composition of the Ipekere Samples (Dry Weight Basis)

\begin{tabular}{|c|c|c|c|c|c|c|}
\hline Samples & M.C(\%) & Ash(\%) & Fat(\%) & Fibre(\%) & Protein(\%) & Carbohydrate (\%) \\
\hline WMD & $8.9 \pm 0.01^{h}$ & $2.47 \pm 0.03^{d}$ & $11.94 \pm 0.06^{c}$ & $7.32 \pm 0.11^{\mathrm{h}}$ & $3.95 \pm 0.06^{g}$ & $65.42 \pm 0.15^{a}$ \\
\hline$W_{M F}$ & $10.83 \pm 0.14^{e}$ & $2.32 \pm 0.02^{\mathrm{e}}$ & $25.04 \pm 0.20^{a}$ & $7.78 \pm 0.11 \mathrm{~g}$ & $5.86 \pm 0.15^{f}$ & $48.14 \pm 0.09^{d}$ \\
\hline$M C 9 D$ & $13.30 \pm 0.04^{d}$ & $2.53 \pm 0.02^{d}$ & $10.27 \pm 0.07^{e}$ & $12.90 \pm 0.17^{d}$ & $11.27 \pm 0.04^{d}$ & $49.73 \pm 0.31^{c}$ \\
\hline $\mathrm{MC9}_{\mathrm{F}}$ & $15.41 \pm 0.02^{c}$ & $2.52 \pm 0.02^{d}$ & $24.85 \pm 0.04^{a}$ & $13.83 \pm 0.24^{b}$ & $11.50 \pm 0.31^{\mathrm{cd}}$ & $31.89 \pm 0.52^{h}$ \\
\hline MC8D & $9.88 \pm 0.04^{g}$ & $2.77 \pm 0.04^{c}$ & $9.89 \pm 0.02^{f}$ & $10.10 \pm 0.12^{e}$ & $12.03 \pm 0.08^{\mathrm{b}}$ & $55.33 \pm 0.22^{b}$ \\
\hline $\mathrm{MC8} \mathrm{F}_{\mathrm{F}}$ & $10.48 \pm 0.03^{f}$ & $2.81 \pm 0.03^{c}$ & $19.78 \pm 0.28^{b}$ & $9.08 \pm 0.07^{f}$ & $11.74 \pm 0.15^{\mathrm{c}}$ & $46.11 \pm 0.45^{f}$ \\
\hline MC7D & $15.80 \pm 0.21^{b}$ & $3.99 \pm 0.03^{b}$ & $8.89 \pm 0.11^{\mathrm{g}}$ & $13.20 \pm 0.21^{c}$ & $10.87 \pm 0.05^{\mathrm{e}}$ & $47.24 \pm 0.38^{e}$ \\
\hline MC7v & $17.47 \pm 0.08^{a}$ & $4.32 \pm 0.17^{a}$ & $16.06 \pm 0.07^{d}$ & $18.76 \pm 0.13^{a}$ & $12.50 \pm 0.11^{\mathrm{a}}$ & $30.90 \pm 0.10^{\mathrm{g}}$ \\
\hline
\end{tabular}

Values with the same superscript in the column are not significantly different $(\mathrm{p} \leq 0.05)$. MC, moisture content, WMF, $100 \%$ maize - control, MC9, 10\% cowpea; 90\% maize, MC8, $20 \%$ cowpea; $80 \%$ maize, MC7, 30\% cowpea;70\% maize. D stands for oven-dried samples while $\mathrm{F}$ stands for oil-fried samples. Letter a-h showed the degree of significant difference.

Table 2. Mineral Composition of the Ipekere Samples

\begin{tabular}{|c|c|c|c|c|c|}
\hline Samples & $K(g / 100 g)$ & $\mathrm{Na}(\mathrm{g} / 100 \mathrm{~g})$ & $\mathrm{Ca}(\mathrm{mg} / \mathrm{kg})$ & $\mathrm{Zn}(\mathrm{mg} / \mathrm{kg})$ & Iron(mg/kg) \\
\hline WMFD $_{D}$ & $5.47 \pm 0.08^{h}$ & $3.13 \pm 0.15^{\mathrm{ab}}$ & $4.31 \pm 0.02^{\mathrm{e}}$ & $0.79 \pm 0.02^{e}$ & $0.67 \pm 0.02^{f}$ \\
\hline WMFF $_{F}$ & $5.90 \pm 0.03^{g}$ & $3.10 \pm 0.02^{a b}$ & $4.60 \pm 0.03^{d}$ & $0.82 \pm 0.02^{e}$ & $0.74 \pm 0.04^{\mathrm{e}}$ \\
\hline$M C 9 D$ & $6.30 \pm 0.03^{f}$ & $2.02 \pm 1.75^{b}$ & $5.40 \pm 0.02^{c}$ & $1.01 \pm 0.03^{c}$ & $0.87 \pm 0.02^{d}$ \\
\hline $\mathrm{MC9}_{\mathrm{F}}$ & $8.60 \pm 0.10^{\mathrm{e}}$ & $3.02 \pm 0.02^{a b}$ & $5.6 \pm 0.05^{b}$ & $1.07 \pm 0.03^{b}$ & $0.90 \pm 0.03^{d}$ \\
\hline MC8D & $9.30 \pm 0.03^{d}$ & $3.50 \pm 0.03^{a}$ & $6.62 \pm 0.03^{a}$ & $0.94 \pm 0.04^{d}$ & $1.39 \pm 0.02^{c}$ \\
\hline$M C 8_{F}$ & $9.86 \pm 0.05^{c}$ & $3.39 \pm 0.03^{a}$ & $6.64 \pm 0.03^{a}$ & $0.96 \pm 0.02^{d}$ & $1.91 \pm 0.02^{a}$ \\
\hline MC7D & $10.50 \pm 0.05^{b}$ & $3.70 \pm 0.03^{a}$ & $6.63 \pm 0.03^{a}$ & $0.97 \pm 0.02^{d}$ & $1.38 \pm 0.03^{c}$ \\
\hline $\mathrm{MC7}_{\mathrm{F}}$ & $16.28 \pm 0.05^{a}$ & $3.81 \pm 0.03^{a}$ & $6.61 \pm 0.04^{a}$ & $1.30 \pm 0.03^{a}$ & $1.49 \pm 0.03^{b}$ \\
\hline
\end{tabular}

Values with the same superscript in the column are not significantly different $(p \leq 0.05)$. K, potassium, Na, sodium, Ca, calcium, Zn, zinc, WMF, 100\% maize - control, MC9, 10\% cowpea; 90\% maize, MC8, 20\%cowpea; $80 \%$ maize, MC7, $30 \%$ cowpea; $70 \%$ maize. $V$ in the samples stands for oven-dried samples while $\mathrm{F}$ stands for oil-fried samples. Letter a-h showed the degree of significant difference.

the oven-dried samples. The ash content of the samples varied from 2.32 to $4.32 \%$, while there was no significant difference in the ash content between the samples produced from $10 \%$ and $20 \%$ cowpea substitution, samples produced from $100 \%$ maize and 30\% cowpea substitution are significantly different in term of ash content. The result obtained for fat determination revealed vast significant differences among the samples, the values which ranged from 11.94 to $8.89 \%$ and 25.04 to $16.06 \%$ for oven-dried and oil-fried samples respectively with the lowest and highest values recorded for oven-dried sample from 30\% cowpea substitution and $100 \%$ maize respectively. The values obtained from fibre determination ranged from 7.32 to $15.76 \%$, the sample with least value was oven-dried $100 \%$ maize $(7.32 \%)$ followed by $100 \%$ maize oil-fried sample $(7.78 \%)$ and the highest value was observed in the sample with $30 \%$ cowpea substitution - oil fried (18.76\%) followed by oilfried sample from 10\% cowpea substitution (13.83\%). Significant differences were also observed in the results obtained from protein and carbohydrate composition. The protein content which ranged from 3.95 to $12.50 \%$ increased with increase in the quantity of cowpea enrichment with the least value recorded for $100 \%$ maize and the highest value recorded for $30 \%$ cowpea enrichment. The carbohydrate composition was significantly different among the samples, the greater the cowpea substitution in the sample, the lower the carbohydrate content. The $100 \%$ maize (oven-dried sample) has the highest value $(65.42 \%)$ while the $30 \%$ cowpea substitution (oil-fried) has the least (30.90\%).

\section{Mineral Composition of Ipekere Agbado Samples}

The result of the mineral composition of the samples as depicted in Table 2 showed significant differences $(p \leq 0.05)$ among the samples. The result obtained in potassium content ranged between 5.47 and 16.28 $\mathrm{g} / 100 \mathrm{~g}$ with the least value obtained for $100 \%$ maize oven-dried sample $(5.47 \mathrm{~g} / 100 \mathrm{~g})$ followed by $100 \%$ maize oil-fried $(5.90 \mathrm{~g} / 100 \mathrm{~g})$ and the highest value recorded for $30 \%$ cowpea substitution oil-fried sample $(16.28 \mathrm{~g} / 100 \mathrm{~g})$. The potassium content was observed to increase with 
Table 3. Microbiological Status of the Ipekere Samples

\begin{tabular}{|c|c|c|c|}
\hline Samples & $\operatorname{TVC}\left(\times 10^{3} \mathrm{Cfu} / \mathrm{ml}\right)$ & $\mathrm{YMC}\left(\times 10^{3} \mathrm{Sfu} / \mathrm{ml}\right)$ & Coliform (x 10 $3 \mathrm{Cfu} / \mathrm{ml})$ \\
\hline WMFD $_{D}$ & $2.4 \pm 0.06^{\mathrm{bc}}$ & $1.1 \pm 0.15^{c}$ & $\mathrm{~N} / \mathrm{A}$ \\
\hline $\mathrm{WMF}_{\mathrm{F}}$ & $2.2 \pm 0.10^{c}$ & $1.0 \pm 0.12^{c}$ & $N / A$ \\
\hline$M C 9 D$ & $1.8 \pm 0.06^{d}$ & $1.6 \pm 0.10^{b}$ & $N / A$ \\
\hline $\mathrm{MC9}_{\mathrm{F}}$ & $2.5 \pm 0.10^{b}$ & $1.8 \pm 0.10^{a}$ & $\mathrm{~N} / \mathrm{A}$ \\
\hline MC8D & $2.7 \pm 0.10^{\mathrm{a}}$ & $1.9 \pm 0.08^{\mathrm{a}}$ & $\mathrm{N} / \mathrm{A}$ \\
\hline MC8F & $2.3 \pm 0.10^{\mathrm{b}}$ & $1.2 \pm 0.10^{c}$ & $\mathrm{~N} / \mathrm{A}$ \\
\hline MC7D & $1.9 \pm 0.05^{\mathrm{d}}$ & $1.0 \pm 0.12^{c}$ & $\mathrm{~N} / \mathrm{A}$ \\
\hline$M C 7 F$ & $1.8 \pm 0.10^{d}$ & $1.3 \pm 0.06^{c}$ & $N / A$ \\
\hline
\end{tabular}

Letter a-h showed the degree of significant difference.

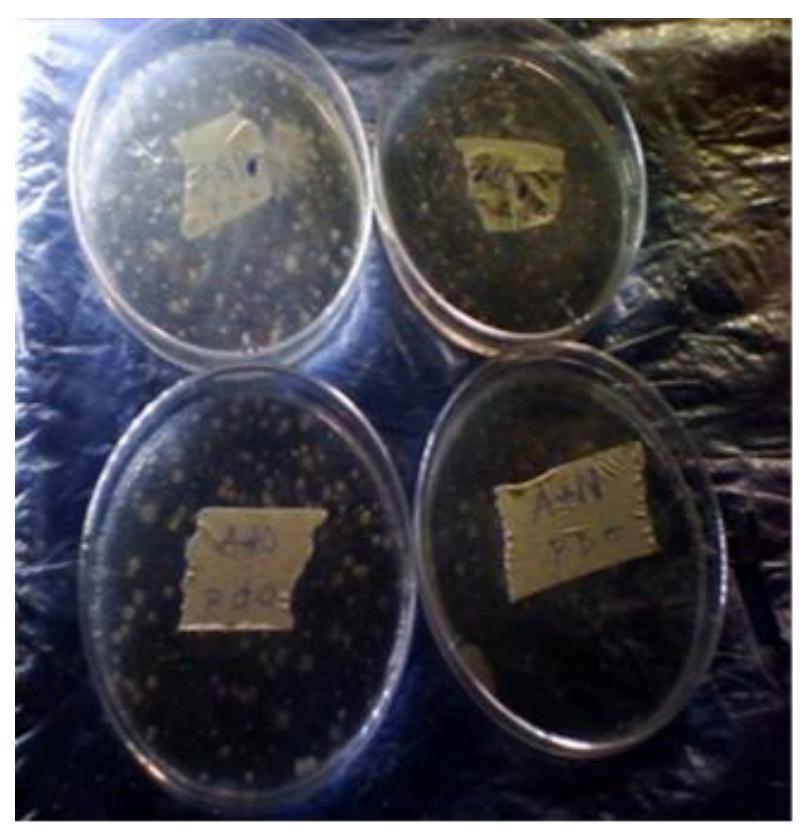

Figure 5: PDA plates showing fungi growth.

increase in cowpea enrichment. The result obtained for sodium content ranged from 2.02 to $3.81 \mathrm{~g} / 100 \mathrm{~g}$, the least value was recorded for oven-dried sample from $10 \%$ cowpea substitution $(2.02 \mathrm{~g} / 100 \mathrm{~g})$ and the highest value for oil-fried sample from 30\% cowpea substitution $(3.81 \mathrm{~g} / 100 \mathrm{~g})$. However, there was no significant difference $(p \leq 0.05)$ among the samples from $20 \%$ and $30 \%$ cowpea substitution in term of sodium and calcium, while the reverse was the case for $100 \%$ maize and $10 \%$ cowpea substitution. The calcium content which ranged from 4.31 to $6.64 \mathrm{~g} / 100 \mathrm{~g}$ increased with increase in cowpea substitution. The zinc content of the samples ranged from 0.79 to $1.30 \mathrm{mg} / \mathrm{kg}$, the sample with the least value was $100 \%$ maize (oven- dried) and the highest value recorded for 30\% cowpea substitution (oil- fried sample). The iron content was observed to increase with increase in the level of cowpea substitution with value ranging from 0.67 to $1.91 \mathrm{mg} / \mathrm{kg}$ for oven-dried sample from $100 \%$ maize and oil-fried sample from $20 \%$ cowpea substitution.

\section{Microbiological Qualities of Ipekere Agbado Samples}

The result of the microbiological evaluation of the sample is presented in Table 3, the Total Viable Count (TVC) ranged from 1.8 to $2.7 \times 10^{3} \mathrm{cfu} / \mathrm{ml}$. There was no significant difference $(p \leq 0.05)$ in the Yeast/Mould Count (YMC) among the following samples; oven-dried $10 \%$ $\left(1.8 \times 10^{3} \mathrm{cfu} / \mathrm{ml}\right)$, oven-dried $30 \%\left(1.9 \times 10^{3} \mathrm{cfu} / \mathrm{ml}\right)$ and oil-fried $30 \%\left(1.8 \times 10^{3} \mathrm{cfu} / \mathrm{ml}\right)$ cowpea substitution respectively but there were significant differences $(p \leq 0.05)$ among the rest samples. The YMC (Figure 5) showed slight differences between the oven-dried and oilfried samples of $10 \%$ and $20 \%$ cowpea substitution with these values 1.6 and $1.8 \times 10^{3} \mathrm{sfu} / \mathrm{ml}, 1.9$ and $1.2 \times 10^{3}$ $\mathrm{sfu} / \mathrm{ml}$. There was no growth on the agar plate that was used to culture coliform which indicated the absence of coliform in samples (Figure 6).

\section{Sensory Evaluation of the Ipekere Agbado Samples}

The mean scores from the sensory evaluation of the samples presented in Table 4 were obtained between 4.11 and 7.11 for sensory attributes tested including aroma, appearance, texture (crispness), taste and overall acceptability. Samples from $20 \%$ cowpea substitution ranked best in terms of aroma, taste, crispness and overall acceptability followed by $10 \%$ cowpea substitution except for taste, while the samples from $100 \%$ maize scored best in appearance followed by the samples from $20 \%$ cowpea substitution. The least scores were recorded for the samples from 30\% cowpea substitution. The oven-dried samples have better appearance and crispness than the oil-fried samples.

\section{DISCUSSION}

The results of the proximate composition of the ipekere 


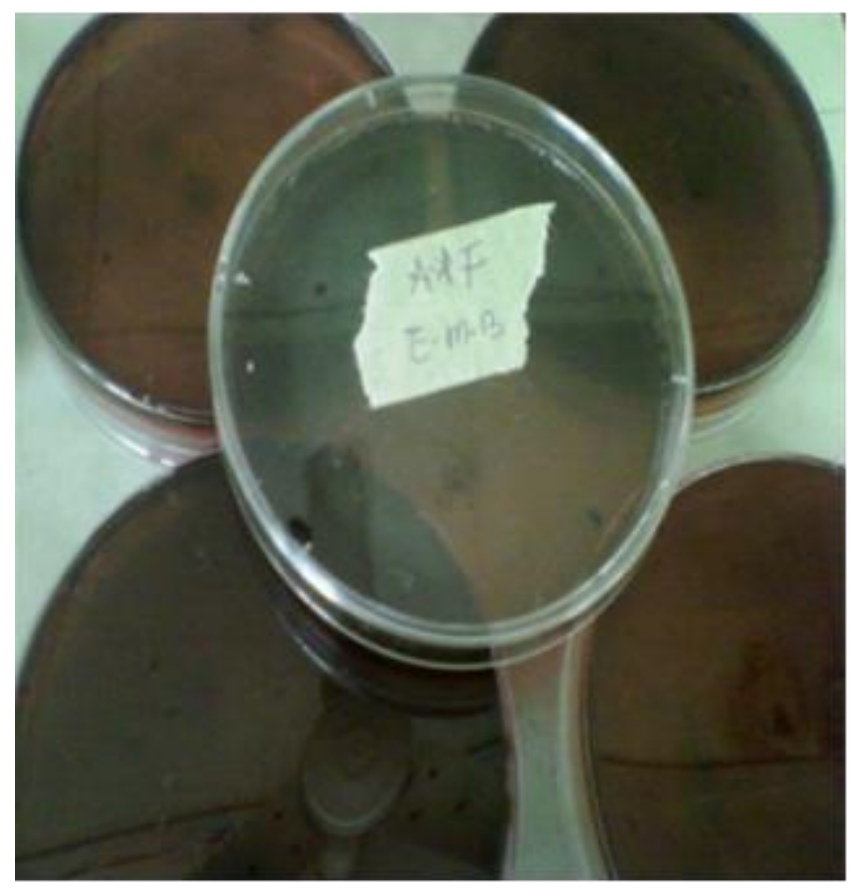

Figure 6: EMB plates showing no growth after incubation.

Table 4: Sensory Properties of the Ipekere Samples

\begin{tabular}{lccccc}
\hline Samples & Aroma & Appearance & Crispness & Taste & Overall acceptability \\
\hline WMF $_{D}$ & $5.05 \pm 0.07^{\mathrm{e}}$ & $6.67 \pm 0.03^{\mathrm{a}}$ & $5.90 \pm 0.03^{\mathrm{f}}$ & $5.43 \pm 0.01^{\mathrm{cd}}$ & $5.20 \pm 0.02^{\mathrm{g}}$ \\
WMFF $_{F}$ & $5.21 \pm 0.02^{\mathrm{d}}$ & $5.93 \pm 0.06^{\mathrm{b}}$ & $5.11 \pm 0.03^{\mathrm{g}}$ & $5.82 \pm 0.07^{\mathrm{b}}$ & $5.60 \pm 0.04^{\mathrm{f}}$ \\
MC9D $_{\mathrm{D}}$ & $5.11 \pm 0.03^{\mathrm{e}}$ & $5.59 \pm 0.03^{\mathrm{d}}$ & $6.30 \pm 0.05^{\mathrm{d}}$ & $5.21 \pm 0.02^{\mathrm{e}}$ & $6.07 \pm 0.07^{\mathrm{d}}$ \\
MC9F $_{\text {MC8D }}$ & $5.30 \pm 0.06^{\mathrm{c}}$ & $5.61 \pm 0.10^{\mathrm{c}}$ & $6.12 \pm 0.02^{\mathrm{e}}$ & $5.41 \pm 0.04^{\mathrm{d}}$ & $6.34 \pm 0.13^{\mathrm{c}}$ \\
MC8F & $5.72 \pm 0.03^{\mathrm{b}}$ & $5.95 \pm 0.08^{\mathrm{b}}$ & $7.20 \pm 0.04^{\mathrm{a}}$ & $5.80 \pm 0.04^{\mathrm{b}}$ & $6.85 \pm 0.10^{\mathrm{b}}$ \\
MC7D $^{\mathrm{b}}$ & $6.06 \pm 0.06^{\mathrm{a}}$ & $5.71 \pm 0.05^{\mathrm{c}}$ & $6.70 \pm 0.03^{\mathrm{c}}$ & $6.06 \pm 0.06^{\mathrm{a}}$ & $7.11 \pm 0.11^{\mathrm{a}}$ \\
MC7F $^{\mathrm{a}}$ & $4.41 \pm 0.02^{\mathrm{f}}$ & $5.64 \pm 0.05^{\mathrm{c}}$ & $6.80 \pm 0.10^{\mathrm{b}}$ & $5.50 \pm 0.04^{\mathrm{a}}$ & $5.25 \pm 0.07^{\mathrm{a}}$ \\
\hline
\end{tabular}

Means with the same superscript in the column are not significantly different $(p \leq 0.05)$. Overall acep., overall acceptability WMF, 100\% maize - control, MC9, = 10\% cowpea; $90 \%$ maize, MC8, = 20\%cowpea; $80 \%$ maize, MC7, = 30\% cowpea;70\% maize. $\mathrm{D}$ in the samples stands for oven-dried samples while $\mathrm{F}$ stands for oil-fried samples. Letter a-h showed the degree of significant difference.

agbado samples were presented in Table 1. The crude protein increased from $3.95 \%$ to $12.50 \%$ as the level of cowpea enrichment increased. The higher protein content of cowpea flour accounted for greater increase in the protein content of the maize and cowpea flour blend used for the snack produced. Similar trend was observed by Otunola et al. (2012) in the study of effect of partially defatted groundnut paste on some properties of kokoro. The carbohydrate content was higher in the $100 \%$ maize than the enriched blends. The ash content ranged from 2.47 to $4.32 \%$ with $100 \%$ maize having the lowest and the blends having the highest, this suggests that cowpea is higher in ash than the maize as opined by Mamiro et al. (2011) who observed the ash content of cowpea to range from 3.75 to $12.87 \%$. Moisture content which is one of the outstanding qualities and widely used parameter in the processing and testing of food qualities was found to range from 8.9 to $17.47 \%$, while the blend with $30 \%$ oil-fried retained the highest moisture, the lowest was recorded for the $100 \%$ maize oven-dried sample. Similar trend was equally observed by Giami et al. (2003) in their study involving proximate composition of akara prepared from cowpea/maize flour blend. The crude fibre and fat contents were also observed to increase with increasing level of enrichment. The crude fibre ranged from $7.32 \%$ to $18.76 \%$ with the oil-fried samples having the highest in each blend. Similar trend was also observed in the fat content of the samples 
which ranged between 8.89 to $25.04 \%$. Oven-drying as a method significantly influenced $(p \leq 0.05)$ the moisture, fibre and fat contents of the samples. The storage life of the oven-dried blend may be increased due to the lower fat contents than the deep-fried samples because all fats and fat containing foods contain some unsaturated fatty acids and hence are potentially susceptible to oxidative rancidity (Ihekoronye and Ngoddy, 1985).

The result of the mineral composition of the samples as depicted in Table 2 showed significant differences among the samples. The result obtained in potassium content ranged between 5.47 and $16.28 \mathrm{~g} / 100 \mathrm{~g}$ with the least value recorded for $100 \%$ maize oven-dried sample $(5.47$ $\mathrm{g} / 100 \mathrm{~g}$ ) followed by $100 \%$ maize oil-fried $(5.90 \mathrm{~g} / 100 \mathrm{~g})$ and the highest value recorded for $30 \%$ cowpea substitution oil-fried sample (16.28 $\mathrm{g} / 100 \mathrm{~g})$. The potassium content was observed to increase with increasing level of cowpea enrichment. This was in agreement with the statement made by Organic Fact (2015) that cowpeas are rich in potassium with good amount of calcium, magnesium and phosphorus. The result obtained from sodium content ranged from 2.02 to $3.81 \mathrm{~g} / 100 \mathrm{~g}$, the least value was recorded for oven-dried sample from $10 \%$ cowpea substitution $(2.02 \mathrm{~g} / 100 \mathrm{~g})$ and the highest value for oil-fried sample from 30\% cowpea substitution $(3.81 \mathrm{~g} / 100 \mathrm{~g})$. However, there was no significant difference $(p \leq 0.05)$ among the samples from $20 \%$ and $30 \%$ cowpea substitution in term of sodium and calcium while the reverse was the case for $100 \%$ maize and $10 \%$ cowpea substitution. The calcium content which ranged from 4.31 to $6.64 \mathrm{~g} / 100 \mathrm{~g}$ increased with increase in cowpea enrichment, this was in contrast with the findings of Chikwendu (2007) in the study of Chemical Composition of Akara Developed from Fermented and Germinated Groundbean and Maize. The zinc content of the samples ranged from 0.79 to $1.30 \mathrm{mg} / \mathrm{kg}$, the sample with the least value is $100 \%$ maize (oven- dried) and the highest value recorded for $30 \%$ cowpea substitution (oilfried sample). The iron content was observed to increase with increase in the level of cowpea substitution with value ranging from 0.67 to $1.91 \mathrm{mg} / \mathrm{kg}$ for oven-dried sample from $100 \%$ maize and oil-fried sample from $20 \%$ cowpea substitution. Though there was limited information for comparison, however, the mineral results concurred with the findings of Bala et al. (2012).

The result of the microbiological evaluation of the sample in Table 3 showed that the total viable count (TVC) was in the range of 1.8 and $2.7 \times 10^{3} \mathrm{cfu} / \mathrm{ml}$, this agreed with the findings of Otunola et al. (2012) whose values ranged from 1.4 to $2.5 \times 10^{3} \mathrm{cfu} / \mathrm{ml}$. There was no significant difference $(p \leq 0.05)$ in the YMC among the following samples; oven-dried $10 \%\left(1.8 \times 10^{3} \mathrm{cfu} / \mathrm{ml}\right)$, oven-dried $30 \%\left(1.9 \times 10^{3} \mathrm{cfu} / \mathrm{ml}\right)$ and oil-fried $30 \%(1.8 \times$ $10^{3} \mathrm{cfu} / \mathrm{ml}$ ) cowpea substitution respectively but there were significant differences $(p \leq 0.05)$ among the rest samples. The yeast and mould count showed slight differences between the oven-dried and oil-fried samples of $10 \%$ and $20 \%$ cowpea substitution with these values 1.6 and $1.8 \times 10^{3} \mathrm{sfu} / \mathrm{ml}, 1.9$ and $1.2 \times 10^{3} \mathrm{sfu} / \mathrm{ml}$ respectively. These were still within the maximum allowable limit of $\left(10^{5}\right)$ and therefore can be said to be fit for consumption. The samples produced also tested negative to coliform test in agreement with similar study carried out by Otunola et al. (2012). Coliform are members of the Enterobacteriacae family and should not be found in food (Ihekoronye and Ngoddy, 1985).

Table 4 shows the results of the sensory evaluation of all Ipekere agbado samples produced. In terms of aroma, deep-fried samples were more preferred to the ovendried samples, while in terms of appearance and texture (crispness), the oven dried samples were more preferred. In terms of taste and overall acceptability, 20\% cowpea blend and the $100 \%$ maize were more preferred. Samples from $20 \%$ cowpea substitution ranked best in terms of aroma, taste, crispness and overall acceptability, this was in line with the findings of Otunola et al. (2012) followed by $10 \%$ cowpea substitution except for taste, while the samples from $100 \%$ maize scored best in appearance followed by the samples from $20 \%$ cowpea substitution. The least scores were recorded for the samples from $30 \%$ cowpea substitution. The oven dried samples were significantly different $(p \leq 0.05)$ from the deep-fried sample from the same blends. Therefore, oven-drying method could be adopted as alternative method for producing the snack since it competes favourably with oil-frying process.

\section{Conclusion}

This study has shown that increasing the percentage of cowpea flour in maize and cowpea flour blends for ipekere agbado production improved the protein and mineral contents of the snack; this indicates a higher nutrient value with respect to protein and mineral contents. The sensory attributes for 30\% cowpea enriched ipekere agbado were least preferred probably because of the strong beany flavour while that of $20 \%$ was most preferred. This shows that $20 \%$ cowpea can be added to ipekere agbado to improve its nutritional value and eating quality. Oven-drying method caused an appreciable decrease in moisture, fat and fibre contents of the samples compared to the oil-fried samples. Though the appearance of the oven-dried samples was most preferred, they scored less in taste. Enriching ipekere agbado with $20 \%$ cowpea resulted in very acceptable products, it can therefore be concluded that to obtain an acceptable cowpea enriched ipekere agbado, the cowpea substitution level should be at $20 \%$.

\section{CONFLICT OF INTEREST}

The authors declare that they have no conflict of interest. 


\section{REFERENCES}

AOAC (1990). Official Methods of Analyses (15 th Ed.) Association of Official Analytical Chemists, Washington D.C.

Barber, L.F., Bebeya, E., Eke Ejiofor, J., Owuno, F. (2010). Effect of Cowpea Supplementation on the Physico-Chemical and Sensory characteristic of "Epiti" a steamed maize and plantain pudding. Journal of Nigeria Food Journal, 28(2), 448-453.

Bala, S. M., Tarfa, B. D., Ado, S. G., Isiyaku, M. F., Makeri, M. U. and Sani, U. (2012). Nutrient and Anti-nutrient Compositions of New Crop Varieties of Cowpea (Vigna unguiculata L.) and Maize (Zea mays). Nigerian Journal of Nutritional Sciences, 33(1),62-67.

Chikwendu, N.J. (2007). Chemical composition of "AKARA" (Fried groundbean paste) Developed from Fermented and Germinated Groundbean (Kerstingiella georcarpa) and Maize (Zea mays) Blends.Journal of Agriculture, Food, Environment and Extension.January,2007 Agro-Science, 6(1), 1-7.

Collins, C. H., Lyne, M., Grage, J. M. (1989): Microbiological Methods (6th Edn), Butter North and Co. Ltd., Pp. 122-135

FAO (1992). Food and Agricultural Organization. Maize in Human Nutrition, UN Rome.

Giami, S. Y., Akusu, M. O. and Jaja, I. R. (2003). Production, Organoleptic Assessment and Nutritional Properties of Akara from Cowpea and Maize Flour Blends. Plant Foods for Human Nutrition, 58, 1-9.

Ihekoronye, A. I., \& Ngoddy, P. O. (1985). Integrated Food Science and Technology for the Tropics. Macmillan Publisher Limited, London, Pp. 241-289.

Iwe, M. O. (2003). Handbook of Sensory Methods and Analysis, Re-joint Communications Services Ltd. Enugu, 8, 71-75.
Mamiro, P. S., Mbwaga, A. M., Mamiro, D. P., Mwanri, A. W. andKinabo, J. L. (2011). Nutritional Quality and Utilization of Local and Improved Cowpea Varieties in Some Regions in Tanzania. African Journal of Food, Agriculture, Nutrition and Development, 11(1), 4490-4506.

Obatolu, V., Omueti, O., \& Ebenezer, A.A. (2006). Qualities of Extruded Puffed Snacks from Maize/Soybean Mixture. Journal of Food Process Engineering 29 (2006), 149-161.

Omueti, O., Morton, I. D., \& Emery, P. W., (1992). Nutritional characteristics of soybean seed flour after processing with sodium bicarbonate or trona. International journal of food sciences and nutrition, 43, 147-153.

Omueti, O. and Morton, I. D. (1996). Development by Extrusion of Soybean Snack Sticks a Nutrionally Improved Soya-maize Product Based on the Nigeria Snack (kokoro). International journal of food sciences and nutrition, 47, 5-13.

Organic Fact (2015) Nutritional Value of Cowpea and Pigeon Pea. Organic Information Services PVT Ltd. Information for Educational Purposes.

Otunola, E. T., Sunny-Roberts, E. O., Adejuyitan, J. A., and Famakinwa, A.O. (2012). Effects of Addition of Partially Defatted Groundnut Paste on Some Properties of "Kokoro" (a Popular Snack made from maize Paste). Agriculture and Biology Journal of North America, Pp. 280-286.

Rhee, K. S., Kim, E. S., Kim, B. K., Jung, B.M., Rhee, K. C., (2004). Extrusion of Minced Catfish with Corn and Defatted Soyflours for Snack Foods. Journal of food processing and preservation. 28(6), 493-496. 